\title{
ARŪNAS BUBNYS
}

Wilno

\section{STOSUNKI MIĘDZYETNICZNE NA WILEŃSZCZYŹNIE W LATACH OKUPACJI NAZISTOWSKIEJ \\ (1941-1944)}

Przynależność państwowa regionu wileńskiego w latach drugiej wojny światowej zmieniała się często. Do wybuchu wojny region wileński należał do Polski, ale Litwa nigdy nie uznała tego faktu, i uważała Wilno za swoją stolicę. Po wybuchu drugiej wojny światowej region wileński 17 września 1939 roku został zajęty przez Armię Czerwoną. W końcu października 1939 roku, na mocy układu z 10 października 1939 roku Sowieci przekazali Litwie Wilno i wąskie pasmo byłego województwa wileńskiego. Litwa otrzymała terytorium o powierzchni $6656 \mathrm{~km}^{2}$. ZSRR zapewnił sobie prawo dyslokacji na Litwie garnizonów Armii Czerwonej - łącznie 20 tysięcy żołnierzy. Litwa odzyskała więc swoją historyczną stolicę, jednak stacjonowanie na jej terytorium garnizonów obcej armii oznaczało początek utraty niepodległości. 15 czerwca cała Litwa dostała się pod okupację Armii Czerwonej, a potem przyłączono ją do ZSRR. Po wybuchu wojny niemiecko-sowieckiej Wilno zostało 24 czerwca zajęte przez Wehrmacht i do 13 lipca 1944 roku znajdowało się pod okupacją niemiecką. Trzecia Rzesza nie zamierzała uznać niepodległości Litwy i wprowadziła na Litwie okupacyjne rządy (Zivilverwaltung). Został utworzony Reichskommissariat Ostland, do którego włączono terytorium Litwy, Łotwy, Estonii i Białorusi. Z byłej Republiki Litewskiej (poza regionem klajpedzkim) Niemcy utworzyli Generalny Komisariat Litwy (Generalkommissariat Litauen), który składał się z czterech okręgów (kowieńskiego, wileńskiego, szawelskiego i poniewieskiego). Centrum administracyjne Litwy znajdowało się w Kownie, tutaj była siedziba generalnego komisarza Litwy, Adriana von Rentelna. Okręg wileński (Gebiet Wilna - Land) obejmował powierzchnię 15840 km², ok. 600 tys. 
mieszkańców. Na tym terenie znajdowały się 53 gminy wiejskie i 5 gmin miejskich ${ }^{1}$. Okręg wileński w latach 1942-1944 obejmował powiaty wileński, trocki, święciański, ejszyszski, oszmianski i swirski. Dwa ostatnie powiaty były przyłączone do Litwy w kwietniu 1942 roku i należały do niej do końca okupacji nazistowskiej, a potem znów włączono je do Białoruskiej SSR. Komisarzem okręgowym na miasto Wilno został Hans Hingst, na okręg wileński Horst Wulff. Największym miastem okręgu było Wilno, według spisu ludności z 27 maja 1942 roku mieszkało tutaj 146 tysięcy osób² 2.

Przed drugą wojną światową okręg wileński był terenem zamieszkiwanym przez wiele narodowości: Polacy, Litwini, Żydzi, Białorusini, Rosjanie. Według polskiego spisu ludności z 1931 roku w województwie wileńskim Polacy stanowili 59,7 proc. (761,7 tys.), Białorusini - 22,7 proc. (289,7 tys.), Żydzi - 8,5 proc. (około 110 tys.), Litwini - 5,2 proc. (65,3 tys.) ${ }^{3}$. Rezultaty spisów ludności w dużym stopniu zależały od tego, która władza je przeprowadzała. W maju 1942 roku, kiedy litewska administracja prowadziła spis ludności w Generalnym Komisariacie Litwy, proporcje grup narodowościowych w okręgu wileńskim były inne, niż w 1931 roku. Z ogólnego spisu ludności z 1942 roku wyłączano ludność żydowską (większość Żydów wymordowano już w 1941 roku) i Niemców, którzy pracowali w administracji niemieckiej oraz formacjach wojskowych. W czterech powiatach otaczających Wilno (wileński, trocki, święciański, ejszyszski) według danych oficjalnych przeważała ludność litewska (58,8 proc.), polska stanowiła 36,9 proc., Białorusinów było 12,9 proc., Rosjan - 2,9 proc. W samym mieście Wilnie Polacy nadal stanowili większość - 71,9 proc., Litwini - 20,5 proc., Rosjanie - 4,1 proc., Białorusini - 2,1 proc. Duża część Polaków i tak zwanych tutejszych podała się za Litwinów lub Białorusinów. Około 15-17 tys. Żydów mieszkało w getcie wileńskim ${ }^{4}$.

Po masowych deportacjach i mordach sowieckich przed wojną i w jej pierwszych dniach nienawiść Litwinów i dużej liczby Polaków do Rosjan była tak wielka, że wkraczające wojska niemieckie były witane jak wybawcy. Wybuchały lokalne powstania antysowieckie. Już 23 czerwca 1941 ro-

1 Ziemie północno-wschodnie w ramach Ostlandu, Litewskie Centralne Archiwum Państwowe (dalej: LCAP), f. R-601, ap. 1, b. 30, s. 2.

2 Ibidem.

3 J. Wołkonowski, ZWZ-AK a problem mniejszości etnicznych na Wilńnszczyznie, [w:] Opór wobec systemów totalitarnych na Wileńszczyźnie w okresie II wojny światowej, Gdańsk 2003, s. 38.

4 P. Eberhardt, Przemiany narodowościowe na Litwie, Warszawa 1997, s. 158, 159. 
ku w Wilnie zaczęli działać litewscy antysowieccy partyzanci, a następnego dnia miasto zostało zajęte przez wojska niemieckie. W tym okresie powstała władza litewska - Komitet Obywatelski Miasta Wilna i Okręgu Wileńskiego. O działalności Komitetu pisano w tajnym biuletynie gestapo z 9 lipca 1941 roku: „Litewskie warstwy, które uważają siebie za aktywistów, zdołały przejacć władzę nad miastem Wilnem i okręgiem wileńskim, gdy tylko wycofała się armia rosyjska. Pod przywództwem Žakevičiusa (docent Uniwersytetu Wileńskiego) powstał Komitet, któremu podległe są różne resorty, między innymi również i resort obrony. Pod kontrolą tegoż Komitetu również część litewskich urzędów rozpoczęła odnowę swej działalności, między innymi policja polityczna, kryminalna i publiczna. Starano się na niemieckich urzędach wojskowych wywrzeć wrażenie, jakoby litewski aparat państwowy był zachowany. Była również odnowiona Litewska Komendantura Wojskowa z litewskim komendantem wojskowym. Ze względu na to, iż litewskie jednostki wojskowe i policyjne Wehrmachtowi były przydatne do ochrony jeńców, mostów, urządzeń kolejowych, magazynów towarowych i broni, jak również zapewnienia porządku publicznego w mieście, początkowo poza pewnymi ograniczeniami powyższa inicjatywa była tolerowana" ${ }^{5}$. Działalność Komitetu nadzorowała niemiecka komendantura wojskowa. Komitet zajmował się sprawami gospodarczymi i administracyjnymi.

Strategicznym celem władz Trzeciej Rzeszy wobec krajów bałtyckich było jak najszybsze przekształcenie ich w niemiecką „przestrzeń życiową”. W instrukcji Alfreda Rosenberga do Reichskommissarza Ostlandu stwierdzono: „Celem Reichskommissarza na Litwie, Estonii, na Łotwie i Białorusi musi być dążenie do utworzenia protektoratu, a następnie przekształcenie go w część Rzeszy Wielkoniemieckiej przez germanizację elementu rasowo bliskiego, kolonizację niemiecką oraz usuwanie elementu niepożądanego" ${ }^{6}$. Te strategiczne cele miały być realizowane po zwycięstwie Niemiec. W czasie wojny Niemcy starali się jak najlepiej wykorzystać podbite kraje dla celów wojennych i gospodarczych. Chociaż Niemcy nie przyznali niepodległości państwu litewskiemu, ważniejsze stanowiska w miejscowej administracji na całej Litwie i w okręgu wileńskim zostały przejęte przez Litwinów. Nie oznacza to jednak, że Litwini cieszyli się specjalnymi względami Niemców. Był to raczej skutek aktywności litewskiej na początku wojny. Jednak trzeba przyznać, że Litwini osiągnęli pewne korzyści z przynależności okręgu wi-

5 K. Škirpa, 1941 metu vyriausybès kelias, „Aidai”, 1971, nr 6, s. 249.

6 P. Eberhardt, Przemiany narodowościowe na Litwie, s. 154. 
leńskiego do Generalnego Komisariatu Litwy, ponieważ władza wykonawcza znalazła się w rękach Litwinów. Niemcy zezwolili na częściową litwinizację Wilna: wprowadzono litewskie nazwy ulic, obok niemieckiego język litewski został uznany za język urzędowy, przy równoczesnym wyeliminowaniu z życia publicznego języka polskiego. Zamknięto polskojęzyczne szkoły, teatry i kina. Władza okupacyjna nadzorowała działalność miejscowej administracji, która miała za zadanie ułatwiać Niemcom opanowanie podbitego kraju i jego eksploatację. Administracja litewska nie miała większego wpływu na decyzje niemieckie. Ze względów propagandowych Niemcy wolały, by niepopularne w kraju zarządzenia były wydawane przez „samorząd litewski”, ściągając odium ludności na tę instytucję. Niemcom brakowało sił do opanowania całego aparatu publicznego, dlatego istnienie „samorządu” było przydatne. Polacy, w odróżnieniu od Litwinów, nie utworzyli organu, który cieszyłby się uznaniem władz wojskowych i cywilnych oraz oficjalnie reprezentowałby ich interesy. Mimo że ważniejsze stanowiska w urzędach wileńskich były w rękach Litwinów, większość urzędników i robotników stanowili Polacy. Niemiecka władza wojskowa po ustaleniu składu narodowościowego Wilna, stwierdzeniu, iż Polacy stanowili najliczniejszą część mieszkańców miasta, wydała rozkaz Komitetowi, aby „na miejskie stanowiska kierownicze dopuścić większą liczbę Polaków” ${ }^{7}$. Postawiono także wymóg, iż „kierownicy urzędów muszą być dobierani na zasadach parytetu ze wszystkich grup narodowościowych, z pominięciem Żydów" 8 . Niemcy często zwracali uwage Komitetu na to, że „w żadnym przypadku nie może doprowadzić do tego, że Polacy czy Białorusini mieliby być dyskryminowani" "9. Komisarz Wilna Hans Hingst 4 sierpnia 1941 roku na spotkaniu z kierownictwem Komitetu na czele z docentem Stasysem Žakevičiusem dobitnie przypomniał, że Litwini w Wilnie stanowią mniejszość i dlatego na miejskie stanowiska kierownicze trzeba przyjąć więcej Polaków, zaś Litwini i Polacy będą przez niego (Hingsta) traktowani jednakowo ${ }^{10}$. Nie można twierdzić, że polityka personalna

7 V. Brandišauskas, Litewska instytucja władzy na poczatku wojny niemiecko-radzieckiej: zarys działalności, kompetencje oraz stanowisko w kwestii stosunków narodowościowych (na przykladzie Komitetu Miejskiego Wilna), w: Opór wobec systemów totalitarnych na Wileńszczyźnie w okresie II wojny światowej, s. 62.

8 Rozkaz nr 1 komendanta Wojennej Komendantury Polowej, 17 lipca 1941 r., Biblioteka Centralna Litewskiej Akademii Nauk, Dział Rękopisów, f. 165-1049, s. 6.

9 Ibidem, f. 165-1045, Opis posiedzenia w wielkiej sali Wojennej Komendantury Polowej, 15 lipca 1941 r., s. 10.

10 Pismo przewodniczącego Komisji ds. Wilna Mačiulisa do gen. P. Kubiliūnasa, 10 sierpnia 1941, LCAP, f. R-617, ap. 1, b. 16, s. 16. 
Komitetu Miejskiego była nacjonalistyczna, czy celowo antypolska. Od początku wojny (22 czerwca 1941 roku) zwolniono z urzędów 727 Litwinów, 1077 Polaków i 142 Rosjan. Większość osób zwolniona była z przyczyn politycznych (komuniści lub zwolennicy rządu sowieckiego) i z powodu likwidacji urzędów ${ }^{11}$. Władze niemieckie dążyły do zachowania stabilności w okręgu wileńskim i nie były zainteresowane eskalacją waśni narodowościowych, dlatego często powstrzymywały ambicje polityczne i nacjonalizm litewski. Ważnym elementem polityki narodowościowej nazistów było stosowanie zasady divide et impera (dziel i rządź). Rozbudzano separatyzmy, skłócano, przeciwstawiano Polaków Litwinom, Białorusinów Litwinom i Polakom, starano się wywołać nienawiść wszystkich narodowości do Żydów ${ }^{12}$. Kiedy Niemcy uznali, że dążenia Litwinów do samodzielności w okręgu wileńskim są zbyt duże, nie zawahali się przeciwstawić Polaków Litwinom. Usiłowano wejść w rolę rozjemcy, interweniując na korzyść ludności polskiej, ochraniając ja od radykalnych antypolskich działań administracji litewskiej. Władza niemiecka uchyliła nakaz nauki języka litewskiego oraz zakaz publikacji w języku polskim. Obwieszczenia w okręgu wileńskim miały być publikowanie $\mathrm{w}$ czterech językach ${ }^{13}$. Z ulic Wilna usunięto flagi i godła litewskie, zastępując je sztandarami ze swastyką. Przykładem na wykorzystywanie przez okupanta konfliktów narodowościowych było zarządzenie z lipca 1941 roku wydane przez ówczesnego komendanta wojennego Wilna Wolfganga von Ditfurtha, które głosiło, że żadna z narodowości zamieszkujących Wilno (Polacy, Białorusini i Litwini) nie jest zobowiązana do nauki języka żadnego poza ojczystym, a jedynie zaleca się naukę niemieckiego. Zarządzenie było skierowane wyraźnie przeciw Litwinom, którzy chcieliby forsować lituanizację ${ }^{14}$. Po wprowadzeniu cywilnej władzy niemieckiej (Zivilverwaltung) 15 września 1941 roku Komitet Miejski Wileński został zlikwidowany i przekształcony w magistrat miejski. Te decyzje władzy niemieckiej wśród Litwinów wywołały wrażenie, że Polacy są „faworyzowani” przez okupanta. To spowodowało skargę na lokalne władze niemieckie. Stosunki litewsko-polskie w okresie okupacji nazistowskiej były napięte i wrogie. Wzajemna wrogość manifestowała się na wszelkie możliwe sposoby: poczynając od konfliktów

11 V. Brandišauskas, op. cit., s. 65.

12 M. Wardzyńska, Polityka narodowościowa Trzeciej Rzeszy w Generalnym Komisariacie Litwy, „Pamięć i Sprawiedliwość”, t. XXXVIII, Warszawa, 1995, s. 110.

13 Ibidem, s. 112.

14 Bekanntmachung des Kommandeurs der deutschen Kommandobehoerde Wilna von 16. Juli 1941, LCAP, f. R-677, ap. 1, b. 1, s. 22. 
w życiu codziennym i bójek ulicznych, a kończąc na otwartej walce zbrojnej. Relacjom litewsko-polskim podczas okupacji nadaje się niekiedy zbyt wielkie znaczenie, traktując je niemalże jak stosunki samodzielnych podmiotów. Nazistowski reżym przede wszystkim dążył do realizacji własnych celów i wykorzystywał podbite narody do urzeczywistnienia swoich planów politycznych. Z drugiej strony, okupowane narody w regionach targanych międzyetnicznymi konfliktami, starały się utrzymać lub wywalczyć pozycję dominującą w stosunku do innych grup narodowościowych. Chociaż podczas okupacji ani Litwini, ani Polacy nie byli prawdziwymi gospodarzami swych krajów, jednak obie nacje w sposób legalny i nielegalny ubiegały się o wpływy na Wileńszczyźnie.

Przykładem takiego postępowania Polaków jest działalność Władysława Komara. Niemcy powołali go na stanowisko zarządcy gospodarstw państwowych, powstałych w dawnych dworach i majątkach na terytorium Gebietskommissariat Wilna-Land. Komar obsadzał wszystkie stanowiska kierownicze miejscowymi Polakami, którzy wykorzystywali, jak tylko mogli, swą pozycję do obrony interesów polskiej ludności. Pomagali zaopatrywać w żywność polską inteligencję w Wilnie, później dostarczali żywność dla oddziałów AK ${ }^{15}$. Jednak naziści, rządząc okupowanym krajem, do połowy 1943 roku bardziej opierali się na Litwinach niż na Polakach. Prawdopodobnie było to skutkiem rasistowskiego stosunku najwyższych przywódców III Rzeszy do narodu polskiego, ale również postawy Polaków w toczącej się wojnie (działalność polskiego rządu emigracyjnego i polskiego podziemia narodowego). Polacy w oczach nazistów byli elementem niebezpiecznym i buntowniczym. Nie bez znaczenia była również wyraźniejsza proniemiecka i antysowiecka orientacja Litwinów. Ale już od drugiej połowy 1943 roku administracja niemiecka wileńskiego okręgu starała się bardziej popierać Polaków, niż Litwinów. Naziści nie odrzucili też zasady divide et impera, która znów była wykorzystana w czasie kolonizacji Litwy w latach 1942-1943. Niemcy chcieli odwrócić uwagę Litwinów od kolonizacji poprzez propagandę, że właściwym ośrodkiem Litwy jest Wilno, dlatego „powinnością dziejową” Litwinów jest kolonizacja Wileńszczyzny i „niesienie tam kultury” ${ }^{16}$. W drugiej połowie 1943 roku na Wileńszczyźnie powstały duże oddziały Armii Krajowej. Ich

15 S. Jegelevičius, Okupacja i kolaboracja na Litwie w czasie II wojny światowej, w: Opór wobec systemów totalitarnych na Wileńszczyźnie w okresie II wojny światowej, s. 35 .

16 M. Wardzyńska, op. cit., s. 117. 
zbrojna działalność zaczęła niepokoić administrację niemiecką. Paradoksalne, ale im aktywniej działała polska partyzantka, tym łagodniejsza była polityka administracji niemieckiej wobec Polaków. Władza niemiecka była zainteresowana podsycaniem konfliktów narodowościowych, liczyła, że uda się przeciwstawić AK partyzantom sowieckim i policji litewskiej. Hitlerowcy, wykorzystując litewską policję bezpieczeństwa i oddziały samoobrony do zwalczania polskiego ruchu oporu oraz do represjowania ludności cywilnej, jeszcze bardziej zaostrzyli antagonizmy litewsko-polskie. W relacjach polskiego podziemia pisano, że Wileńszczyzna zaczyna być terenem trudnych konfliktów narodowościowych: „niewątpliwie Niemcy byliby poparli dążenia litewskie, gdyby potencjał siły litewskiej okazał się godnym poparcia. Tymczasem, porównanie wypadło na korzyść Polaków. Stąd płyną próby pojednawcze w stosunku do społeczeństwa polskiego, jak dotąd bez rezultatów. Inicjatywa wyszła raczej ze strony Wehrmachtu, który radby przede wszystkim pozyskać dla swych celów bojowy element polski" ${ }^{17}$. W pierwszej połowie 1944 roku Niemcom już nie udało się opanować sytuacji i kontrolować konfliktów narodowościowych i politycznych na Wileńszczyźnie. Administracja okupanta utrzymywała władzę tylko w samym Wilnie i w centrach powiatowych, a wieś wileńska była już w rękach partyzantów polskich lub sowieckich.

W okręgu wileńskim Niemcy próbowali stworzyć nacjonalizm białoruski i wykorzystać go przeciw Litwinom i Polakom. Już 9 lipca 1941 roku dowództwo Einsatzkommanda 8 meldowało naczelnym władzom Rzeszy w Berlinie o politycznej sytuacji na Wileńszczyźnie w sprawie białoruskiej: „Zum Ausgleich gegen sehr aktive litauische Taetigkeit wurde seitens der Einsatzgruppe dem Wilnaer Sekretaer der frueheren weissruthenischen Partei, Ladislaus Kozłowski Erleichterungen im Aufbau einer weissruthenischen Volkstumsstelle genehmigt" ${ }^{18}$. Władza niemiecka próbowała politycznie uaktywnić grupy białoruskie o nastawieniu germanofilskim. Białorusinom pozwolono na: nadawanie audycji białoruskich w radiostacji wileńskiej, wydawanie swojej gazety („Bialoruski Holas”), otwarcie gimnazjum i seminarium nauczycielskiego w Wilnie, stworzenie Komitetu narodowego, działaczom białoruskim proponowano udział w administracji okręgu. Odbywało się to kosztem ludności polskiej, którą zwalniano ze sprawowanych

17 Archiwum Akt Nowych w Warszawie, Sygn., 202/II-51, s. 74.

18 M. Wardzyńska, Sytuacja ludności polskiej w Generalnym Komisariacie Litwy czerwiec 1941-lipiec 1944, Warszawa 1993, s. 132. 
funkcji (w powiatach oszmiańskim i swirskim). Ale próby neutralizowania aktywności litewskiej ruchem białoruskim nie powiodły się. Za przyczynę Niemcy uznali słabe dążenia narodowe i niewielką liczbę osób o cechach przywódczych wśród Białorusinów ${ }^{19}$.

W interpretacji Hitlera wojna Niemiec ze Związkiem Radzieckim miała być walką dwóch światopoglądów, walką o zniszczenie. Zakładano rozbicie państwa komunistycznego i wytępienie bolszewizmu. Stąd też przede wszystkim planowano fizyczne zniszczenie nosicieli bolszewickiej idei i zarazem członków aparatu przywódczego (funkcjonariusze państwowi i partyjni oraz komisarze Armii Czerwonej). Ludność żydowska, w której naziści widzieli rdzeń i biologiczny rezerwuar bolszewizmu, miała być zupełnie zlikwidowana. Antysemityzm hitlerowski był wykwitem doktryny rasistowskiej, doprowadzonej do absurdu. Eksterminacja Polaków, Rosjan i innych narodowości miała jakieś zbrodnicze uzasadnienie w chęci rozbudowy państwa czy powiększenia Lebensraumu, Żydzi powinni być zniszczeni totalnie jako rasa. Realizacja zadania mordowania wrogów Trzeciej Rzeszy została powierzona operacyjnym grupom policyjnym (Einsatzgruppen der Sicherheitspolizei und SD). W krajach nadbałtyckich, w tym i na Litwie, działała Einsatzgruppe A i jej Einsatzkommandos 2 i 3. W okręgu wileńskim na początku działało Einsatzkommando 9, a od 9 sierpnia 1941 roku Einsatzkommando $3^{20}$. Od pierwszych dni wojny i okupacji naziści rozpętali antykomunistyczną i antyżydowską propagandę i nawoływali miejscową ludność do „oczyszczenia się” z Żydów. Wśród części społeczeństwa i administracji litewskiej antysemicka propaganda nazistowska odniosła spodziewany skutek. Jak na całej Litwie, tak i na Wileńszczyźnie w prasie i radiu od pierwszych dni okupacji stosowano retorykę antyżydowską. Charakterystycznym zjawiskiem było utożsamienie Żydów z komunistami. Z rozkazu komendanta wojskowego armii niemieckiej z 3 lipca 1941 roku Komitet Miejski Wilna wydał ogłoszenie zobowiązujące Żydów do noszenia gwiazdy Dawida oraz wprowadzające godzinę policyjną od 6 . wieczorem 6 . rano ${ }^{21}$. Już od pierwszych dni okupacji rozpoczęła się akcja zwalniania z pracy Żydów i członków organizacji komunistycznych. W połowie lipca 1941 roku rozpoczęła się masowa zagłada wileńskich Żydów. Gestapo w Wilnie stworzyło oddział specjalny (Sonderkommando), który przystąpił do rozstrzeliwania Żydów

19 M. Warzyńska, Polityka narodowościowa..., op. cit., s. 114.

20 Idem, Sytuacja ludności polskiej..., s. 36.

21 V. Brandišauskas, op. cit., s. 64. 
w Ponarach, około $7 \mathrm{~km}$ od miasta. W doprowadzeniu Żydów do Ponar i w ochronie miejsca zagłady brały udział także litewskie bataliony policyjne, stacjonujące w Wilnie. 4 września 1941 roku Niemcy wydali rozkaz zamknięcia Żydów w getcie, a wykonanie zlecili litewskiej policji. Getto zostało podzielone na dwie odrębne części, oddzielone ulicą Niemiecką. W pierwszym getcie umieszczono tak zwanych fachowców i zamożniejszych Żydów, a w drugim biedotę, stłaczano tam po kilkanaście osób w jednym pokoju. Pod koniec października drugie getto zlikwidowano, a w pierwszym pozostali jedynie potrzebni Niemcom specjaliści (około 17 tysięcy osób), posiadający karty pracy ${ }^{22}$. Do końca 1941 roku zamordowano około 33-35 tysięcy wileńskich Żydów. Równocześnie przeprowadzono egzekucje w innych miastach i miasteczkach okręgu wileńskiego. W końcu 1941 roku dowódca Einsatzkommando 3 Karl Jaeger w raporcie dla władz w Berlinie pisał: „Moge dzisiaj stwierdzić, że cel, rozwiązanie problemu żydowskiego na Litwie, został przez Einsatzkommando 3 osiągnięty. Na Litwie nie ma już Żydów, poza żydowskimi robotnikami i ich rodzinami” ${ }^{23}$. Żydowskich robotników pozostawiano na wyraźne żądanie administracji cywilnej i Wehrmachtu. Pracowali głównie dla potrzeb armii niemieckiej. Getto wileńskie zostało zlikwidowane przez Niemców w końcu września 1943 roku. Największą część Żydów wileńskich wywieziono do miejsc straceń w Estonii, Łotwie i w Generalnej Guberni. Z około 60 tysięcy Żydów wileńskich wojnę przetrwało tylko 2-3 tysięcy osób. Dlaczego zagłada Żydów na Litwie była prowadzona tak szybko i radykalnie? Jedną z możliwych odpowiedzi jest ta, że Holocaust, jako państwowa polityka Trzeciej Rzeszy, był związany z planami kolonizacji i germanizacji krajów bałtyckich. Litwa sąsiadowała z Niemcami i jej terytorium powinno być jak najszybciej „oczyszczone” z niepożądanych elementów. Przede wszystkim takim elementem „niepożądanym” byli właśnie Żydzi. Ważne było jeszcze to, że według nazistów Żydzi na zapleczu frontowym byli niebezpieczni dla reżymu okupacyjnego i dlatego trzeba było ich zlikwidować. Warto dodać, że eksterminacyjna polityka nazistów wobec Żydów znalazła poparcie administracji litewskiej. Litewska policja, bataliony policyjne, oddziały byłych partyzantów antysowieckich (nazywanych przez Polaków szaulisami) stały się narzędziem okupanta w prowadzeniu eksterminacji Żydów. Dlatego Holocaust na Litwie miał takie tragiczne skutki.

22 Stosunki polsko-litewskie w świetle czterech okresów okupacji Wilna i Ziemi Wileńskiej, AAN, Sygn. 211/16, s. 20.

23 Masinès žudynès Lietuvoje, d. 1, Vilnius 1965, p. 136. 


\section{Zakończenie}

Strategicznym celem Trzeciej Rzeszy wobec krajów nadbałtyckich była aneksja do Rzeszy, ich kolonizacja i germanizacja. Germanizacji podlegała tylko 1/3 Litwinów (ta część, która według nazistów miała krew nordycką). Pozostała część Litwinów i Polaków powinna być przesiedlona na wschód, do Białorusi i Rosji. Żydzi powinni być totalnie wymordowani. Realizacja tych planów miała być wykonana po wygranej wojnie. Bieżącym celem reżymu okupacyjnego na Litwie było maksymalne wykorzystanie zasobów gospodarczych i ludzkich dla celów wojennych. Dlatego administracja niemiecka była zainteresowana stabilnością kraju, unikaniem ostrych konfliktów politycznych i narodowościowych. Najważniejszym źrodłem konfliktów narodowościowych w okręgu wileńskim były antagonizmy litewsko-polskie. W pierwszych latach okupacji (do połowy 1943 roku) polityka administracji niemieckiej była przychylniejsza wobec Litwinów. Litwini zajęli najważniejsze stanowiska w administracji okręgu wileńskiego, faktycznie w ich rękach znalazła się władza wykonawcza. Z drugiej strony, władza niemiecka kontrolowała działalność administracji litewskiej i nie pozwalała na polityke dyskryminacyjną wobec Polaków, Białorusinów i Rosjan. Do hamowania aspiracji i ambicji politycznych Litwinów Niemcy próbowali wykorzystać Polaków i Białorusinów. Zasadę divide et impera naziści stosowali również wobec Polaków (wsparcie ruchu białoruskiego przeciw Polakom). We wszystkich narodowościach próbowano wzbudzć antysemityzm. Od drugiej połowy 1943 roku polityka niemiecka wspierała Polaków. Chociaż polski ruch oporu zaczął stwarzać dużo problemów dla okupacyjnej administracji, władza niemiecka unikała masowych represji wobec polskiej ludności. Dlatego sytuacja wileńskich Polaków była stosunkowo lepsza niż mieszkańców Generalnej Guberni.

Polityka wobec ludności żydowskiej od samego początku była dyskryminacyjna i bezwzględna. Już w pierwszym miesiącu okupacji zaczęła się masowa eksterminacja Żydów. Najwięcej żydowskich mieszkańców okręgu zamordowano do końca 1941 roku. Wileńskie i święciańskie getta były zlikwidowane w 1943 roku. Zagłada Żydów była prowadzona nie tylko przez gestapo, ale i przez różne formacje policji litewskiej. Okupację hitlerowską przetrwało tylko 2-3 tysiące wileńskich Żydów.

Polityka niemiecka wobec Białorusinów i Rosjan była umiarkowana i stosunkowo łagodna. Niemcy popierali narodowe odrodzenie Białorusinów, oświatę, pobudzali polityczną aktywność i udział Białorusinów w miejscowej administracji. Próbowali wykorzystać nacjonalizm białoruski przeciw 
Litwinom i Polakom. Niewielka liczba inteligencji białoruskiej nie pozwoliła Białorusinom na uzyskanie znaczącego wpływu w okręgu wileńskim. Administracja niemiecka popierała też religijne i kulturalne życie Rosjan, propagowała wyjazdy Rosjan na roboty do Niemiec, starała się odseparować Rosjan od wpływów bolszewizmu.

Możemy stwierdzić, że polityka narodowościowa okupanta w okręgu wileńskim, była stosunkowo umiarkowana (poza likwidacją narodu żydowskiego). Administracja niemiecka starała się utrzymać stabilność kraju i nie dać się rozwinąć konfliktom międzyetnicznym.

\section{Inter-ethnic relations in Vilnius Region during Nazi occupation (1941-1944) \\ Summary}

The strategic aim of the Third Reich towards the Baltic Sea countries was their colonization and germanization. $1 / 3$ of the Lithuanians were to be germinized. The rest of the Lithuanians and Poles were to be resettled east. In the first years of the occupation German administration's policy was favorable towards the Lithuanians. They took the most important posts in the local administration of the Vilnius district, moreover, they held executive power in their hands. On the other hand, the German administration controlled the activity of the Lithuanian administration and did not allow to discriminate Poles, Belorussians and Russians. The Germans tried to take advantage of the Poles and Belorussians to restrain the Lithuanians' political aspirations. All nationalities were incited against Jews. In the second half of 1943 the German policy was already favorable towards Poles. The occupants avoided mass repressions. What is more, the German policy towards Belorussians and Russians was moderate and relatively soft. The Germans supported national rebirth of Belorussians. They tried to take advantage of Belorussian nationalism against Lithuanians and Poles. The German administration supported religious and cultural life of the Russians, propagated Russians' "trips" to Germany to work there, encouraged them to join the police and army, and tried to separate the Russians from the impact of bolshevism.

\section{Межэтнические отношения на Виленщине в годы нацистской оккупации (1941-1944) Резюме}

Стратегической целью третьего рейха по отношению к прибалтийским странам была их колонизация и германизация. Германизации должна была подвергнуться $1 / 3$ литовцев. Остальные литовцы и поляки должны быть переселены на восток. В первые годы оккупации политика немецкой администрации в отношении к литовцам была благоприятной. Они заняли самые главные 
посты в местной администрации виленского округа, в их руках была исполнительная власть. С другой стороны, немецкая администрация контролировала деятельность литовской администрации и не разрешала ей дискриминировать поляков, белорусов и русских. В качестве тормоза политических стремлений литовцев немцы пытались использовать поляков и белорусов. Все национальности натравливались на евреев. Во второй половине 1943 г. немецкая политика уже была направлена на поляков. Оккупанты избегали массовых репресий. Также немецкая политика по отношению к белорусам и русским была умеренной и относительно мягкой. Немцы поддерживали национальное возрождение белорусов. Пытались использовать белорусский национализм против литовцев и поляков. Немецкая администрация поддерживала религиозную и культурную жизнь русских, пропагандировала выезды русских на работу в Германию, наклоняла их вступать в полицию и армию, пыталась изолировать русских от влияния большевизма. 